\title{
TRIPARTITE RELATION BETWEEN CHINA-TIBET-INDIA AND INDIA'S RESPONSE TO TIBETAN QUESTION
}

\author{
Rahul Kumar \\ Ph.D. Research scholar, Centre for Russia and Central Asia Studies CRCAS SIS JNU
}

Article DOI: https://doi.org/10.36713/epra5264

\begin{abstract}
Tibet is situated geo-strategically as buffer state between China and India and is critical to India's security. Tibet was ruled by theocratic head of states like Dalai Lama which served socio-political culture of Tibet before 1949. Mao's military intervention led to the occupation of Tibet. The hostility between India and China emerged after Dalai Lama and his followers fled to India and were given asylum here. In 1959 there was suppression by Chinese PLA to quell down the Tibetan uprising my militarily and control over its territory has increased tension between two countries. India has recognised the Tibet as autonomous region of PRC while contrary China should also recognise Sikkim, Arunachal Pradesh and Jammu \&Kashmir as states of Indian union on reciprocal basis. India has urged Dalai Lama on earlier stances to seek peaceful settlement with Beijing and which will enhances the Tibet autonomy. Dalai Lama visited India during 1956 and stayed here permanently while Nehru urged to return back to Tibet and work on the basis of Seventeen point programme. The political and monistic elites of Tibet's has tried to squeeze out the concession from China by exploiting the popular discontent from there. India's security interest and concerns primarily lies in the eliminating and reducing the Chinese military presence in the Tibet. China has relationship with India and ask for endorsing the "one china policy" with regard to Tibet. India needs to re-evaluate and re-look at the Tibetan policy from the prism of national security and its religious tolerance to Tibet. There has been linkages of Buddhist philosophy between Tibet and India and acknowledges its threads to India. This Buddhist philosophy worked as Guru-Patron or Choe-yon relationship between India and Tibet. The Tibetan refugee settlement, Buddhist monasteries and educational institutions as these institution playing crucial role to maintaining traditional culture and identity of Tibet.
\end{abstract}

KEY WORDS: occupation, reciprocal, endorsing, acknowledges, re-evaluate.

\section{INTRODUCTION}

There has been close connectivity between India and Tibet in terms of historical, cultural and religious linkages over past two millennium. There is triangular relationship between China-India and Tibet enmeshed with stalemated relationship with border disputes. Tibet served as a vassal state and protectorate for the Qing Empire till 1912 which caused the basis for territorial claim of China over Tibet. Tibetans are quite thankful to religious and culturally, generous and magnanimous to hospitality provided by Indians in age of realism. The Tibetan studies revolves around the anthropological studies of art, culture, Buddhism, religion and Language of Tibetan peoples. India by providing Tibetan refugees in exile home has played the role of Tibetan cause for freedom. This is considered as an act of courage and conviction by allowing to accepting compassionately Tibetan refugees shelter in India who are escaping Chinese occupation and oppressive regimes there. Thus Dharmsala is looked as a little Lhasa. (Dharan: 2003) Thus Tibetan Government in exile has served as the vital interest for India and has enjoyed the hospitality offered by India since 1959. India host the TGIE Tibetan government in exile and Dalai Lama. 


\section{TIBETANS REFUGEES AND DIASPORA AND LIVING IN EXILE}

The paper in this segment focusses on notion of Tibetans living in exile for more than fifty years. Many peoples are displaced because of wars, economic instability and genocide. After Chinese occupation of Tibet and subsequently Flight of Dalai Lama in India there has been more than 1 Lakhs registered refugees in India. The Government in exile functions in Dharamsala after 1960s headed by Dalai Lama. They are lauded for preserving successfully their culture and identity in exile. The Tibetan refugees feel that India is their second home. The Tibet has been exploited for its natural resources. The Tibetans Lamaist Buddhists are widespread to parts like Sikkim, Ladakh, Nepal, Bhutan, Mongolia, and Russia (Buryat Mongolia, Tannu, Tuva and Kalmyika). There has always been nostalgia for the Tibet they dwell and stayed. Tibetans expressed the sense of gratitude for India being generous host though it is another home which portrayed on their mental map. (Tarodi: 2011:17)

\section{INDIA, CHINA, TIBET AFFAIRS AND INDIAN PERSPECTIVE FROM SECURITY PRISM}

Tibet acts as a buffer state to India and China has been huge cause of concern due to heavy militarization and by Chinese administration. India has been considered as greatest centre of learning. Tibet is geopolitically and strategically situated in the far flung from west side of Xinjiang region. Tibet remained a long inconclusive and protracted, undetermined type of conflict which has made it flash point between Sino-India as Taiwan is potential flashpoint of conflict between United States and South China Sea. By systematically destroying the buffer status of Tibet China has pushed India to permanent state of strategic disadvantage. Indian leader BR Ambedkar has quoted that allowing China to hold its position and occupation over Tibet and exercising its control on Lhasa Nehru has done strategic blunder and had made deep inroads for bringing PLA to Indian frontiers and bordering regions. (Muni: 3) India has decided in favour and permitted the "Tibetan autonomy under the Chinese suzerainty". After historical panchsheel agreement made in 1954 India was forced to bring back its "military outposts located at Yatung and Gyantse of Tibet. (ibid: 3)

Thus India was more concerned for the national security and rather than supporting Chinese liberation and unification programme. There was large scale militarization in Tibet as there were many military positions constructed in Ladakh. The threat perception of Sino-India relations emerges from the history and destiny of Tibet. China has used the coercive power to sabotage the secessionism and integrate the periphery into China. Security of the refugees are also cause of concern and few Refugees might be Chinese agent in disguised form. There has been nuclearisation of Tibet by China around Lhasa and Ngapa Tibetan Autonomous and Kham province. The bonhomie between Sino-India was turned into adversarial situation when Tibet was acting as a friendly buffer state and baggage of spiritual legacy when Tibet provoked animosity and hostility between two countries. India's holistic development and global order values of peace were compromised by Chinese ulterior motive to nuclearize Tibet. (Mehrotra: 42)

\section{CHINA AND TIBET HISTORICAL ASSERTION AND CLAIMS}

Chinese has the perception of Tibet as an inalienable part of China's territory. Tibet having distinct language, history and culture and religion affirms that Tibet was an Independent nation- state. There are question to ponder over that is Tibet a Country. (Dolma: 14) The core debate revolve over the status of Tibet as politically and historically Tibet has been inalienable part of China while Tibetans asserts and protests that Tibet has been independent country. Tibet was protectorate of Manchu- Chinese Empire against the west Mongol threat. The relationship between Chinese emperor and Tibet's Dalai Lama was patron Priest relationship. Historically Tibet was included as vassal state during Qing dynasty and subsequently Chinese proclaimed Tibet as part of China. (Dolma: 15)

The Chinese troops entered and barged into the Chamdo province to clampdown the movement by smashing death of Tibetans and killing regional governor Nagapo Ngawang Jigme. The two provinces of Tibet were reduced and balkanise as Sichuan and another Yunnan were gradually assimilated and incorporated into China. The remaining portion of Amdo was incorporated into Gansu province. (Mehrotra: 24) Dalai Lama served as secular and ecclesiastical ruler of the Tibet. Mao planned for military intervention in early 1950s. Mao's wanted to transform it into People's democratic Tibet. Mao was aware of the rivalry between Dalai Lama in Lhasa and Panchen Lama in Rikaze. Subsequently Chinese authority and Chinese Communist party tried get support of Panchen Lama to get Legitimacy over Liberation of Tibet. (Jian: 59)

The Shimla convention of 1914 between British India, Independent Tibet and China is treaty which legitimises the legality of McMahon line. India, Tibet and China come together to resolve the issue pertaining to status of Tibet and its border with Tibet. (Reappraisal of India's Tibet Policy 2013:20) 
There are four requirement for statehood they are population, territory, government exercising control over Population and Territory, capacity to enter relations with other states. There has been proindependence movement which has been quelled by detaining the activists there. The Tibetan people's right to self-determination is more robust and has gained momentum after continued repression as there has been 99 and many more cases of selfimmolations. The PRC has not acted as legitimate government and claim for territorial integrity has caused Tibet for self-determination rights. The entry of PLA into Tibet is inferred as an illegal act of aggression. Thus the goal post of Tibet has been changing over period of time by his holiness and Excellency Dalai Lama middle way approach to autonomy, self-government, and right to selfgovernment. (Dharan: 2003) Dalai Lama when started talk with Deng on China's autonomy Dharamsala explained that exile community rangbtsan (independence or self-determination) had been abandoned in favour of rang-skyong-ljong (autonomy). (Norbu: 4)

There would always be separatist threat from Tibet autonomy and Tibetan national identity would pose challenge to China. The Chinese Communist party has labelled Dalai Lama as separatist and he is travelling abroad since 1980s to familiarise people with Tibetan issue and create a lobby for Tibetan People. After 2007 China is trying to cut the influence of Dalai Lama by alienating and isolating him by pressurising foreign leaders and governments not to officially receive him.(Ranade:3)

Dalai Lama has remained a bone of contention between India-China official interactions during Track I and Track II talks. After Internationalisation of Tibetan issue it got substantive attention and prominence. Dalai Lama addressing to US congress has proposed five point peace plan as: converting Tibet as a Zone of Peace, Abandoning Chinese population transfer policy without threatening Tibetans, Respecting fundamental rights and democratic freedoms, protection of environment and continued negotiation for settlement of Tibetan issue. (Kemenade: 58)

\section{CHINA INDIA GROWING HOSTILITY AND RESPONSE TO TIBETAN QUESTION}

India was committed to resolve and recognise the integrated one China policy of PRC by accepting Tibet as an autonomous part of China by preserving the cultural and religious identity intact. Dalai Lama is political and religious head of Tibetan Buddhism community and cultural autonomy encapsulates the notion of giving freedom to worship. Chinese are reluctant and hesitant to concede more then freedom to profess and practice right to worship, while Tibetans wants to control foreign, defence and currency. (Muni: 11)

Regarding Chinese aggressive postures and notorious designs and Tibetan independence movement Bihar's leader Jay Prakash Narayan has vocally and emphatically said that Tibetan struggle for right of Mans during the late 1960s addressing All India Tibet Conference. Lok Nayak argued that Tibetan movement can't be futile and lost forever as the spirit of human being is immortal, and Tibet can't die and I will be sooner than later renovated and rejuvenated. JP Narayan put forwarded by eloquently saying that "Tyrannies have come and gone and ceasers, czars and dictators. But the spirit of man goes forever. Tibet will be resurrected." (Mehrotra: 26)

There was sceptical relationship between China and India with bitter sense of animosity and friction prevailed at the moment when Dalai Lama and his followers were given asylum in India.in 1959. The border tension other issues between Sino-Indian relations got escalated when the Chinese PLA's tried to quell the rebellion from Tibet and Chinese wanted to control and supress the Tibet militarily and politically. KPS Menon the then India's deputy foreign minister expressed deep concern over China's PLA entry into Tibet in 1950 in response Mao drafted response by saying that "Tibet is Chinese territory and Tibet is exclusively part of Chinese internal affairs". Earlier stances during 1950s India has officially denounced the PLA's armed intervention in the Tibet and India has criticised the cynical attitude of China remorsefully by sending official notes and memorandum. (Jian: 81)

\section{INDIA, BUDDHISM AND DALAI LAMA THE RELIGIOUS FACTOR AND INTRIGUING QUESTION OF TIBET}

Buddhism is definitely the soft power being pursued by India to create bonhomie between two countries. The Buddhism acts as a tool for cultural integration and re-energize the relationship of two countries. For China Buddhism is equally important to integrate the domestic discontent and disintegration and preserve the territorial integrity of country. India has carried forward the legacy of Buddhism to promote the public diplomacy and inculcated it into policy makers of country. India's bond with other countries has increased because of Buddhism as it is part and parcel of spiritual heritage and has leverage over the outreaching the other countries.

Dalai Lamas have constantly contested for the China's sovergnity over Tibet. Chinese fear for secessionist movement in Tibet to liberate Tibet and echoing of Free Tibet sloganeering there. Dalai Lama 
visited India during 1956 to participate into 2500 years of Buddha's birth. He informed the Indian authorities about the Chinese nefarious plan in Tibet. PM Nehru insisted to return back to China and work for enduring relationship with China. Dalai Lama has softened his attitude towards China and has abandoned his desires to Deng Xiaoping's by submitting his quest for Tibetan Independence which Deng is reluctant to offer and instead he focuses on and has asked for full autonomy to Tibet. (Muni: 5)

During late 1956 there was official stay of Dalai Lama to the holy land of Buddhism where he conclusively decided to stay permanently and work from here. India was overwhelmed by Lama but his presence was questionable and suspicious. Indian Prime Minister without provoking Chinese premier pleaded Dalai Lama to get back to China and work with them on peaceful seventeen point Programme there.(Jian: 83)

Buddhism has played a significant role in the development of Tibetan linguistic and cultural heritage. As stated and said by Falcone Wangchuk in 2008 quote unquote that for many Tibetan in India is a "home away from home". (Dolma: 10) Tibetan Buddhism has been reaching out and spreading to Chinese society from late 1990s. There has been cultural and religious integration and revival of Tibetan and Himalayan region Buddhism after settlement of Tibetan Diaspora. Dalai Lama has aptly described the "Indians as Guru and Tibetans as their Chelas i.e. disciple.”(Dolma: 12)

There has been pertinent question and debate to ponder over how religion has transcended beyond borders and has global footprint felt. Thus Tibetanisation and Tibetan Buddhism got prominence and momentum. Tibetans lamas are reaching out to the problems associated with the Chinese society. These Lamas are allowed to deliver special lectures in university regarding social ethics, morality and globalisation. Lamas are pushing for cohesiveness and social engagement in Chinese society through Buddhism. This Tibetan Buddhism came from India and has been preserved through ages for civilizational linkages. Tibetans are relegitimising the social presence of Tibetan Buddhism in China is soft power projection. (Yu: 2016)

The relentless and untiring work of Dalai Lama got acknowledged and he was awarded Nobel Peace prize in 1989 for his amicable and peaceful solution for Tibetan movement. The complex problem of Tibet got spotlight and there was growing feeling of disgust and hatred for Chines police terror and appreciation for Dalai Lama's peaceful nonviolent solution for Tibet issue. China considered that Tibetan High priest has been converted into agent of western forces playing into their hand to enervate, contain and disintegrate China. (Kemenade: 60)
Buddhism as worked as a bridgehead between two civilisations of countries. Buddhism has been deliberately and purposefully incorporated into foreign policy articulation and diplomatic interaction of two countries. Tibet is the immediate issue between India and China where the relationship between two countries got entangled and enmeshed. Dalai Lama served as the head of Tibetan theocracy of Gelugpa School and controlled the political power. The second school was influenced by Panchen Lama. Karmapa was the highest leader of Kagyu School. Tenzin Gyatso who is the 14th Dalai Lama had to escape from Chinese threat and took asylum and shelter in Himalayas for seeking sanctuary in 1959 in India which flared up the relationship and worked as divisive politics between two countries.(Scott: 156)

The Chinese government were irked and provoked by the creation of (TGIE) Tibetan government in Exile by Central Tibetan Administration, CTA at Dharmsala which detoriated the relationship to low level. The Indian government has given due permission to Dalai Lama to visit Twang in 2009 infuriated the relationship with china in 2009. This led to disagreement and dissonance in relationship between two countries. As Ambassador David Scott clearly states that China has been fearful and anxious of growing legitimacy and sense of insecurity that Buddhism as a soft power has political control over Tibet. Thus Buddhism spills across the Sino-India border which remains elusive in foreign policy and domestic policy. Further David Scott says that China remains hypersensitive to the foreign interference and meddling into Tibetan Buddhist affairs which portrayed as a insecurity dilemma for weakening security control over Tibetan Buddhism.(Scott:162)

The China's ambition to assimilation and liberation of Tibet was formidable task perhaps, the democratisation process initiated by China was never a Peaceful as it culminated to massive death tolls. The liberation caused death of millions of Tibetans and more than Thousands cultural centres, monasteries were decimated and destroyed by China. Also during the Cultural Revolution (1966-76) PRC in Tibet has destroyed the numerous monasteries, places and other aspects of Buddhism. China has been waiting for the demise of compelling personality Dalai Lama which has the potential for unlocking the China's longstanding problem with Tibet which is eagerly watching for disintegration of Tibetan movement. (CRS 2008:11)

Preservation of Tibetan Culture and language seems to be a daunting task as it is facing subversive threat from the China. The Tibetans freedom to travel abroad and attend the religious pilgrimage was curtailed and their passports were intentionally destroyed by the Chinese immigration authority for Tibetans attending Dalai Lama's 
teaching in Bodhgaya. Now the local Tibetans are acultured and even intermarry within the ethnic groups. There is provision for cultural rights of ethnic minorities shall be guaranteed echoing the provision of PRC ethnic Autonomy law and PRC education law for respecting and securing to use their own ethnic languages. Tibetan language and culture face the marginalisation and Chinese government and party is enforcing the Mandarin Chinese as main language for instruction in Tibetan areas. Then the recent incident of Tashi Wanghchuk was set to trial at Yushu province as there was allegations regarding charges of inciting separatism and was criticising the government for preserving the Tibetan Culture and languages. (Tibet: 5)

\section{BUDDHISM AS TRACTION IN INDO- TIBETAN RELATIONSHIP}

Tibetan pilgrims used to visit Gaya, Sarnath and Sanchi associated with live of Buddha. Indeed its great pleasure that. XIV Dalai Lama and other senior Lamas are valuable assets to India for international diplomacy. The re-establishment of ancient historical Buddhist institute of learning Nalanda University is major step in this regard. There has been cultural and religious linkages between India and Tibet over more than 2000 Years, where Tibetan Buddhism is influenced and guided by key philosophy and teachings obtained from India as well as its script. The establishment of Tibetan refugee's settlements, Buddhist monasteries and educational institutions have played a significant role in spreading the Tibetan identity and culture, preservation of heritage across country. The philosophy deeply embedded in the Monastic system and government (religious/political) was basic framework for Tibet's relationship with neighbouring states India as (GuruPatron, Guru-shishya or Choe-yon relationships). (Reappraisal of India's Tibet Policy: 22)

Tibetans has developed the Lamaist society which founded the Sakyapa, Kadampa and Kagyudpa schools of Tibetan Buddhism. Similarly the relationship between Tibets and Mongols was unique as priest-patron relationship as cho-yon. Tibet received protection from Buddhist Mongol emperor and in returned by providing spiritual guidance from Lamas of Tibets thus relationship involved the reciprocal legitimacy of authority. (Dulaney and Cusack: 7)

\section{RECENT TIBET UPRISING AND OUTRAGE IN 2008}

During Olympics 2008 Tibetans protested against the Chinese as many Lamas took over the streets in Lahasa. Police was there to suppress the revolt and rebellions by arrest and detention. Chinese army quelled the rebellion killing many Lamas.
There was international attention once again on the territory which was ignored for moment. International court of Justice has declared that selfdetermination is acknowledged right and cannot be misappropriated. Tibet has been part of Manchu government and Tibet is independent state with its own sovereignty over its territory. (Yu Emily)

The Buddhist monks during the Olympic 2008 marched around the Lhasa to mark the 49th anniversary of Tibetan uprising against Chinese rule. March 10, 2008 marked the 49 ${ }^{\text {th }}$ years of unsuccessful Tibetan uprising against Chinese rule in 1959. There was similar kinds of protests and demonstrations spreading out from Tibetan Autonomous regions TAR spreading out in parts of Sichuan, Gansu and Qinghai provinces with Tibetan population. (CRS 2008) There were numerous cases of self-immolations in the Tibet autonomous areas of China. There has been repressive policies followed by China in Tibetan Autonomous areas where there is use of extensive and intrusive surveillance, stringent measures which restricts the Tibetan's fundamental rights and pervasive displays of military and police forces.( Tibet:4)

\section{CONCLUSION}

The paper deles into nuanced way the Tibetan question and imbroglio faced by India China and Tibet. The relationship with China has slumped and there is growing manifestation of doubt and distrust due to Tibet Hostages in India. Although India has shown appositive gesture by accommodating the Tibetans by providing another abode hear in India. There has been certain changes and continuity in our policy regarding China, by showing Kindness and leniency to Tibet issue. The fragile relation has been maintained despite adversarial situations between two countries as Tibetan aspirations long live and continue to be unabated. The syncretic and composite culture is bonded by Buddhism in region.

\section{REFERENCES}

1. Dharan, Anjali J. (2003), Indo-Tibetan Political Relations: Past, Present, and the Future of Tibet, Emory-IBD Tibetan Studies Program Dharamsala, India (Spring 2003).

2. Dolma, Dawa (2017), Survival and revival of Tibetan Ethnic identity in India, Social Affairs. Vol.1 No.6, 1-23, Spring 2017.

3. Dulaney, Andrew $G$ and Dennis M. Cusack (1998), Tibet's sovereignty and the Tibetan's people's right to self-determination, Tibet Justice Center.

4. Dumbaugh, Kerry (2008), Tibet: Problems, Prospects, and U.S. Policy, CRS congress report for congress Specialist in Asian Affairs Foreign Affairs, Defense, and Trade Division.

5. Jian, Chen (2006), The Tibetan Rebellion of 1959 and China's Changing Relations with India and 
the Soviet Union, Journal of Cold War Studies Vol. 8, No. 3, Summer 2006, pp. 54-101@ 2006 by the President and Fellows of Harvard College and the Massachusetts Institute of Technology.

6. Kemenade, Willem van (2008), Détente between China and India the Delicate Balance of Geopolitics in Asia, The Hague, Netherlands Institute of International Relations 'Clingendael' Clingendael Diplomacy Papers No. 16.

7. Mehrotra, L.L (1997), India's Tibet Policy An Appraisal and Options, Tibetan Parliamentary and Policy Research Centre C-1/1267, Vasant Kunj New Delhi-110070.

8. Muni, S. D. (2009), The Tibetan 'Uprising' 2008: India's Response, ISAS working paper No. 59Date: 1 June 2009.

9. Norbu, Dawa; China's Tibet Policy, A Compilation of a series of Programs on Radio Free Asia, Tibetan Service.

10. Ranade, Jayadeva (2017), Buddhism: A new frontier in the China-India Rivalry, Carnegie Endowment for International Peace, CarnegieIndia.org.
11. Reappraisal of India's Tibet Policy (2013), Foundation for Non-violent Alternatives (FNVA), New Delhi 110049, India.

12. Scott, David (2016), Buddhism in Current China-India Diplomacy, in: Journal of Current Chinese Affairs, 45, 3, 139-174.

13. Tarodi, Tunga (2011), Revisiting Home: Tibetan Refugees, Perceptions of Home (Land) and Politics of Return, the Institute for Social and Economic Change, Bangalore.

14. Tibet and India's security: Himalayan region, refugees and Sino-Indian relations, IDSA Task Force Report, 2012, New Delhi.

15. Tibet, Status of Negotiations between the Chinese Government and the Dalai Lama or His Representatives.

16. Yu, Emily, the Tibet-China Conflict and Controversy, Taipei Municipal Zhong Shan Girls High School.

17. Yu, Prof. Dam Smyer (2016), A Tibetan soft Power: Revisioning Buddhism as a science of the mind in China, Institute of Chinese Studies, Delhi.

\section{Acknowledgment/ Bio Note: \\ Rahul Kumar}

Ph.D. Research scholar Centre for Russia and Central Asia Studies CRCAS SIS JNU

BIO Note: Rahul Kumar is Doctoral student at CRCAS SIS JNU pursuing his Ph.D. on Russia's perception of Global terrorism 2001-2017. Has done his MA and M.Phil. From SIS JNU. I am working under the Supervision of Dr. Nalin Kumar Mohapatra. His M.Phil. Topic is Russia-China strategic interactions and implications for India's security. I want to pursue my career in research and development field of international studies, beside this I have career dream of foreign policy watch and analyst of country to assess the different international, global political scenarios and international turmoil, insurgence and its impact on country. Beside this I am interested in Pursuing Academic excellence by imparting education by teaching and I have academic and literary bent of mind to follow these events passionately by actively participating in seminars and conferences across the length and breadth of country. 